Vauclair, C. M. (2009) Measuring cultural values at the individual-level: considering morality in cross-cultural value research. Revista de administração Mackenzie, vol. 10, no. 3 [online] Available at http://www.scielo.br/pdf/ram/v10n3/a05v10n3.pdf (access date: 12.12.2016).

White, L. A. (1959) The Concept of Culture. American Anthropologist, vol. 61, no. 2, pp. 227-251.

Submission date: 03.04.2017.

Касаткин Петр Игоревич - кандидат политических наук, доцент кафедры мировых политических процессов Московского государственного института международных отношений (Университета) Министерства иностранных дел Российской Федерации. Адрес: 19454, Россия, г. Москва, пр-т Вернадского, д. 76. Тел.: +7 (495) 434-91-62. Эл. адрес: pkas@mail.ru

Kasatkin Pyotr Igorevich, Candidate of Politology, Associate Professor, Department of World Politics, Moscow State Institute of International Relations (MGIMO University), Ministry of Foreign Affairs of the Russian Federation. Postal address: 76, Vernadskogo Ave., Moscow, Russian Federation 119454. Tel.: +7 (495) 434-91-62. E-mail: pkas@mail.ru

DOI: $10.17805 / z p u .2017 .4 .14$

\title{
Семиотическое пространство культуры Русского Севера
}

\author{
Л. В. МИХАЙЛОВА
}

ПЕТРОЗАВОДСКИЙ ГОСУДАРСТВЕННЫЙ УНИВЕРСИТЕТ

Семиотическое пространство культуры Русского Севера включает Валаамский и Соловецкий архипелаги, а также топонимы, характеризующие духовное и материальное бытие Спасо-Преображенских монастырей, природные объекты, флору и фауну региона. Актуальность исследования обусловлена возрастающим интересом к духовно-нравственному, историко-культурному и ландшафтному пространству Русского Севера, духовность которого определяется фундаментальной ролью Соловецкого и Валаамского православных монастырей. Целью данной статьи является определение культурно-исторического, топонимического и ландшафтного пространств Русского Севера. Задачи исследования соотнести духовную культуру северных монастырей с материальной и природной культурой Русского Севера; выявить роль мирских названий культурных ландшафтов Валаамского и Соловецкого монастырей.

В статье представлены результаты эмпирического исследования геокультурного пространства Валаамского и Соловецкого монастырей. Для определения семиотического пространства Соловков и Валаама использованы методы сбора информации, лингвистического анализа выявленных в ходе полевых исследований и из различных источников названий географических объектов, расположенных на островах Валаамского и Соловецкого архипелагов; использован синтез различных подходов: философских, исторических, географических, религиозных, литературных. Исследование топонимии Валаама русского происхождения проводилось в 2000-2012 гг. и опубликовано в научных статьях и в монографии «Валаам: Град Земной - Град Небесный» (Михайлова, 2013). В данной статье впервые публикуется классификация топонимов, характеризующих природу Валаама. Следующим шагом нашего исследования является изучение семантики и структуры компонентов топонимов, описывающих хозяйственно-экономическую деятельность Соловецкого монастыря. Полевые, архивные и другие исследования проводились автором на островах Соловецкого архипелага в 2012-2016 гг. и опубликованы в научных статьях и в монографии «Преображение Русского Севера» (Михайлова, 2015). Классификация то- 
понимов островов Соловецкого архипелага, представленная в данной статье, более полно отражает различные виды деятельности Соловецкого монастыря, его историю и природу. На основе собранного топонимического материала автор впервые проводит также сравнительный анализ семиотического пространства Соловков и Валаама.

Семиотическое пространство Русского Севера характеризуют названия природных объектов, расположенных на островах Валаамского и Соловецкого архипелагов, а также топонимы, описывающие культурное пространство, хозяйственно-экономическую деятельность Спасо-Преображенских монастырей. Топонимы, созданные разными поколениями людей, раскрывают гармонию рукотворного и природного ландшафтов, дополняют культурный образ монастырей Русского Севера.

Ключевые слова: Валаам; Соловки; семиотическое пространство; система знаков; монастырь; культурно-ландшафтный комплекс; топоним; Русский Север

\section{ВВЕАЕНИЕ}

$\mathrm{C}$ емиотическое пространство культуры Русского Севера включает Валаамский и Соловецкий архипелаги, а также топонимы, характеризующие духовное и материальное бытие Спасо-Преображенских монастырей, природные объекты, флору и фауну региона. Актуальность исследования этой темы обусловлена возрастающим интересом к духовно-нравственному, историко-культурному и ландшафтному пространству Русского Севера, духовность которого определяется фундаментальной ролью Соловецкого и Валаамского православных монастырей, переживших периоды разорения и восстановления. Целью исследования является определение культурноисторического, топонимического и ландшафтного пространств Русского Севера. Задачи исследования: соотнести духовную культуру северных монастырей с материальной и природной культурой Русского Севера; выявить роль мирских названий культурных ландшафтов Валаамского и Соловецкого монастырей.

Основу нашей работы составляют результаты эмпирического исследования геокультурного пространства Валаамского и Соловецкого монастырей. Аля определения семиотического пространства Соловков и Валаама были использованы методы сбора информации, лингвистического анализа, выявленных в ходе полевых исследований и из различных источников названий географических объектов, расположенных на островах Валаамского и Соловецкого архипелагов; использован синтез различных подходов: философских, исторических, географических, религиозных, литературных. Исследование топонимии Валаама русского происхождения проводилось в 2000-2012 гг. и опубликовано в монографиях автора (Михайлова, 2013, 2015). Следующим шагом нашего исследования является изучение семантики и структуры компонентов топонимов, описывающих хозяйственно-экономическую деятельность Соловецкого монастыря. Полевые, архивные и другие исследования проводились автором на островах Соловецкого архипелага в 2012-2016 гг. и опубликованы, в том числе, в монографии (Михайлова, 2015).

На основе собранного топонимического материала автор впервые проводит сравнительный анализ семиотического пространства Соловков и Валаама.

\section{НАУЧНАЯ ИЗУЧЕННОСТЬ ПРОБАЕМЫ}

Аля изучения культуры региона, его семиотического пространства необходимо погружение в язык и систему знаков.

Первые исследования, посвященные языку, встречаются уже в трудах античных философов, в средневековой схоластике, в учениях А. Аокка, Г. В. Аейбница. Ю. М. Аотман связывал идею культуры с понятием семиосферы, включающей вер- 
бально-письменные (словесные) языки устного и письменного общения, коммуникации и фиксации текстов; языки художественные (музыки, танца, скульптуры, живописи и т. п.); языки технических систем (математические, компьютерные, языки дорожных знаков и указателей и т. А.) (Иотман, 1993: 328-329). Основы семиотики были разработаны в 1920-1930-е годы структуралистами, членами пражской лингвистической школы, представителями которой являются Н. С. Трубецкой, Р. О. Якобсон; американской школы - Ч. Пирс, Ч. У. Моррис; французской структурно-этнографической (антропологической) школы - К. Аеви-Строс.

Э. Кассирер считал сущность и функции языка важнейшей системой в культурносимволическом универсуме человека (Кассирер, 1993: 23-24). Аля исследования языка необходимо обращение к работам П. А. Флоренского (Флоренский, 1990), А. Ф. Мосева (Иосев, 1990), М. М. Бахтина (Бахтин, 1979), О. М. Фрейденберг (Фрейденберг, 1998), а также современных российских ученых: Б. В. Маркова (Марков, 2001), Н. Б. Мечковской (Мечковская, 1998).

Методология исследования сакральной географии Севера разработана в исследованиях Н. М. Теребихина (Теребихин, 1993), В. Н. Матонина (Матонин, 2013), Мелютиной М. Н. (Мелютина, Попова, Теребихин, 2015), В. В. Скопина (Скопин, 2008), Г. М. Керта (Керт, 2009) и др. В. В. Скопин считает, что в настоящее время пример Соловков как места, куда столетиями в поисках духовности стекались сотни тысяч люАей, приобретает особый смысл (Скопин, 2008: 240). Он описывает историю и природу Соловков, архитектурные памятники Соловецкого монастыря. Н. М. Теребихин проводит сравнительно-типологическое исследование традиционной культуры и пространственного менталитета народов европейской Арктики (русских поморов, норвежцев, саами, ненцев, коми); исследует систему городской топонимики и семантику сакрального топонима «Архангельск» (Теребихин, 1993). Особенный интерес представляет его маргинальный образ острова как элемента сакральной географии и центра монастырской жизни Русского Севера, какими, по нашим представлениям, являются острова Валаам и Соловки. В. Н. Матонин анализирует духовные и психологические аспекты северной русской колонизации, рассматривает феноменологию концепта «северность», онтологические качества «севера» как социокультурного пространства (Матонин, 2013). В 2016 г. учеными Северного (Арктического) федерального университета (САФУ) издана коллективная монография «Сакральная география и иеротопия Русского Севера», авторами которой являются Н. М. Теребихин, $\Lambda$. А. Попова, М. Н. Мелютина (Мелютина, Попова, Теребихин, 2015). В книге опубликованы результаты исследований в области сакральной географии Кенозерского национального парка.

Г. М. Керт является выдающимся ученым Карельского научного центра РАН, исследователем прибалтийско-финской и русской топонимии, автором более двух с половиной сотен публикаций, в том числе в иностранных журналах и научных сборниках (Финляндия. Франция, Германия, Венгрия). В монографии «Саамская топонимная лексика» Керт характеризует особенности саамской топонимии Кольского полуострова, степень ее изученности, излагает основные сведения о саамах и их языке (Керт, 2009).

\section{ВААААМСКИЙ МОНАСТЫРЬ}

Аля проведения анализа хозяйственной деятельности Валаамского монастыря и его культурно-семиотического пространства автором были определены все объек- 
ты, расположенные на островах Валаамского архипелага, выявлены их названия, составлены топонимические карты (Михайлова, 2012).

Монастьрское хозяйство. Культурно-ландшафтный комплекс Валаамского монастыря, расположенный на островах Валаамского архипелага, включает центральный монастырский ансамбль с главным Спасо-Преображенским собором; ансамбли скитов, конюшню, ферму, аллеи, яблоневые сады, заводы. Хозяйственно-экономический уклад Валаамского монастыря был основан на различных видах деятельности: от занятий сельским хозяйством до развития туризма на Валааме, что подтверждают названия объектов с лексемами: рыбачий, кирпичный, смоляной, ферма, конюшня, завод и ар.

Изучение топонимического материала, собранного в ходе полевых, камеральных и других исследований, позволило нам выделить следующие виды деятельности Валаамского монастыря.

1) Садоводство. Монастырские сады создавали представление о райском саде как о месте вечного блаженства. Валаамский монастырь с собором и келейными корпусами окружают три яблоневых сада: Верхний или Аптекарский, Средний и Нижний. В садах произрастали яблони, груши, несколько сортов крыжовника, смородина, малина. В Аптекарском ботаническом саду выращивали лекарственные и декоративные растения: мяту, шалфей, майоран, полынь и др. Монастырские сады называли по именам людей, которые заботились о них, например: сад Паисия, сад Григория. Яблоневые сады были на островах Скитском, Святом и на других островах Валаамского архипелага, где монахи жили в скитах.

2) Земледелие. К западу от Валаама расположены небольшие острова с названиями Ржаной и Овсяный. В Валаамском монастыре были поля: Гороховое, Турнепсовое и другие, которые засевались ячменем, овсом, рожью, турнепсом, картофелем, горохом. Пахотные участки, сенокосные угодья на Валааме имеют также свои названия, например: Железняковская Пожня, Новая Пожня, Аолгое Поле, Никоновское Поле, Грязное, Горбатое (Национальный архив Республики Карелия - НА РК. Ф. 762. Оп. 1. А. 1/126).

3) Молочное животноводство. Основное молочное хозяйство монастыря размещалось на берегу Среднеостровского озера, к западу от монастыря, где в 1881 г. Иоанафаном с братией построена монастырская молочная ферма. В красном кирпичном доме с подвалом была устроена паровая машина, поднимавшая воду наверх, оттуда вода по трубам подавалась в дом. По подземным чугунным трубам вода поступала на скотный двор. При помощи паровой машины сбивали здесь масло, мололи муку, резали солому для корма скота.

4) Рыболовство. На ферме был устроен Рыборазводный завод, в котором разводили рыбу из икры, преимущественно палии и сига. Весной, в мае месяце, рыба выпускалась в озеро, соединенное каналами с Мадогой, в количестве до 40 тыс. мальков и более.

Скажем о хозяйственно-экономической деятельности монастыря, которую характеризуют топонимы Первая Точка, Вторая Точка, Бредневый, Неводной. «Точки» являются северным и восточным мысами Валаама, где монахи занимались рыбной ловлей, и находился Аетний скотный двор. К востоку от Валаама расположен остров с топонимом Бредневый. Бредни - это сетки типа невода. Около острова у монахов был садок для загона рыбы, из которого они ловили ее бреднем. Подобные названия имеют восточная бухта и восточный мыс Валаама: Неводная бухта (Бредневый залив; 
Нуотталахти; Nuottalabti - финск. яз.); Неводный мыс (Невод; Нуоттаниеми; Nuottaniemi - финск. яз.); а также расположенные в северной части острова мысы Садковые и остров Садковый. В Монастырской бухте Валаама лежит остров Рыбачий. Второе название острова Байонной также Рыбачий (Kalastussaari - финск. яз). На этом острове монастырские рыбаки занимались рыболовством. В XIX в. здесь находилось небольшое поселение рыбаков, для которых были построены деревянные дома и часовня во имя св. пророка Елисея.

5) Cmроительство. Аля того чтобы воссоздать «портрет» Валаамского монастыря, его структуру, особенности быта, обратимся к следующим фактам. В середине XIX в. Валаамскому монастырю было положено по штату 70 монахов и столько же послушников. Вместе с богомольцами население монастыря составляло постоянно около 200 человек (НА РК. Ф. 762. Оп. 1. А. 3/30а). По ведомости монастыря за 1863 г. среАи монашествующих были: настоятель, 14 иеромонахов, в том числе 3 схимонаха, 61 послушник и 84 богомольца (Валаамский монастырь, 1864: 259).

На Валаам приглашали одних и тех же мастеров из различных губерний. Так, столярные и плотницкие работы выполняли костромские мастера, штукатурные - ярославские, каменотесные и кирпичные - мастера из Карелии. Неповторимые архитектурно-ландшафтные ансамбли Валаама создавали и профессиональные архитекторы из Петербурга: А. М. Горностаев, Г. И. Карпов, Н. И. Баранкеев и др. К северу от Валаама, при входе в Монастырскую бухту, на небольшом острове, соединенном с Валаамом деревянными мостами, расположен ансамбль Никольского скита. Первоначальное название острова - Крестовый. В давние времена на его вершине стоял деревянный крест, а позднее деревянная часовня. В 1809 г. на ее месте была построена каменная часовня во имя Святителя Николая. Она служила маяком для рыбаков и путешественников. По всем сторонам часовни были сделаны окна, сквозь которые в темные ночи и во время туманов пробивался свет от зажженного в ней фонаря и освещал путь к монастырю. По проекту А. М. Горностаева на месте часовни построена кирпичная церковь (1850-1853) во имя Николая Чудотворца, или Николая Угодника, покровителя земледелия и урожая, водной стихии, спасителя моряков и рыбаков, которого в народе называли Никола Морской. Остров был переименован в Никольский. Также по проекту архитектора А. М. Горностаева в 1849 г. построен новый каменный храм на Скитском острове. За восемь лет здесь отстроился заново скит во имя Всех Святых (Большой скит), расположенный в 5 км от монастыря. Восемь келейных корпусов соединяла каменная ограда с башнями по краям. Кроме келий в скиту размещались фотография, трапезная и кухня, были погреба и кладовые.

Иноки бережно относились к природе Валаама. На островах было запрещено использовать деревья для строительства, в лесах велись только санитарные рубки, лес очищали от валежника. Все строительные материалы завозились с материка. Видимо, с перетаскиванием деревьев связан топоним Выволок (Вюволок, финск. Vyvolok) название северо-восточной оконечности острова Скитский. Этот западный входной мыс бухты Монастырской, окаймленный каменистой отмелью, лежит напротив Валаама. Волоком в старину называли перешеек между двумя бассейнами, по которому переволакивали суда. Слово «волок» имело также значение «путь лесом, перегон лесом». В словаре В.Ааля: «Волок - глухой лес, непроезжий бор, из которого лето и зиму выволакивают срубленные бревна на полозках, на волоках» (Ааль, 1989: 236). Возможно, валаамский топоним Выволок произошел от глагола выволакивать: «выволакивать, выволокать, выволочить, выволочь, выволокчи, выволокнуть - извлекать, 
вытягивать, вытаскивать, доставать таском или волоком. Выволакиванье, выволокание, выволоченье, выволок, выволока, выволочка» (там же: 282).

Таким образом, бережное отношение к природе, строгое соблюдение монастырского устава позволили инокам Валаамского монастыря сохранить и приумножить богатства острова. Валаам в прошлом, хотя и не был заповедником, жил в режиме строгой заповедности. Образ жизни в монастыре, отлаженное крепкое хозяйство вызывали удивление даже у современников. Известный русский писатель И. С. Шмелев в путевых очерках писал: «Валаам - точно маленький промышленный городок, убежавший от мира и разбросавший свои постройки на скалах среди лесов и проливов, на неспокойных водах неприютной Аадоги» (Шмелев, 1897: 98). Спасо-Преображенский Валаамский монастырь, владения которого простирались далеко за пределы Валаамского архипелага, в XIX в. укрепил свои границы, окреп экономически, приобрел значение крупного духовного и культурного центра Русского государства.

В начале XX в. Валаамский монастырь также считался одним из крупнейших в России. Кроме иноков в монастыре жили паломники и молодые люди из Приладожья, Олонца и других районов России, обучавшиеся ремеслу в монастырских мастерских. Общее количество населения Валаама составляло более тысячи человек.

Строительство Смоленского скита, расположенного в южной части острова Скитский, на Смоленском полуострове, связано с трагическими событиями истории Валаама. Это последний, тринадцатый, скит Валаамского монастыря, основанный накануне Первой мировой войны. Скитский храм во имя иконы Смоленской богоматери, построенный в 1917 г., дал название скиту. Второе название Смоленского скита Ефремовский. В скиту жил схимонах отец Ефрем, который был духовником главнокомандующего армией русской империи Великого князя Николая Николаевича. В благодарность этому Великий князь вместе с другими членами императорской семьи - друзьями о. Ефрема построил скит для своего духовного отца. Отец Ефрем является автором рукописи о последних днях членов царской семьи и их смерти, написанной в 1922 г. Он был с семьей царя Николая II в Екатеринбурге и был свидетелем приближающейся ужасной кончины бывшего царя и его семьи (НА РК. Ф. 762. Оп. 1. А. II/123. $\Lambda .1-2$ ).

6) Ремесла. Аля создания наиболее полной картины сложившегося к XIX в. крепкого и обширного хозяйства Валаамского монастыря необходимо отметить развитие кузнечного, кожевенного и других ремесел и создание как на Валааме, так и на других островах архипелага заводов, обеспечивающих монастырь различной продукцией. Так, один из первых на Валааме заводов был построен монахами по дороге к Никольскому скиту. Это Смолевой завод, на котором выгоняли из сосновых пней смолу и скипидар. На территории завода была также установлена печь для обжигания извести из мрамора, которую использовали в строительстве. Многие строения не сохранились до наших дней, и узнать об их местоположении мы можем из названий бухт и островов, где они находились: Старозаводской (залив), Старого Завода (мыс), Кузнечные (острова), Кирпичный (канал). Бухта и островок напротив маленькой монастырской мельницы, в одной из юго-восточных бухт Валаама, называются Мельничными. Топоним Берег Кожевенного Завода (бухта) подтверждает, что именно в северной части Валаама монахи занимались кожевенным ремеслом (Михайлова, 2012).

Происхождение следующих топонимов имеет также отношение к хозяйственной деятельности Валаамского монастыря. Так, в районе Феодоровской бухты можно пройти по дороге до Первого песочка. Этих объектов три, они представляют ряд ма- 
леньких бухт с ровным дном. Песок использовали в строительстве, а черный блестящий песок, покрывающий берег острова Аембос, применяли в монастыре для присыпки чернил (чтобы лучше высыхали), а также продавали. Аембос расположен к востоку от Валаама, в Байоновском заливе. В 1867 г. здесь был устроен скит Ильинский с деревянной церковью св. пророка Ильи. С этого времени остров стал называться Ильинским.

В восточной части Валаама монахи также добывали песок, этот район известен под названием Карьер. Топоним «Кирпичный» относится к объектам, расположенным около кирпичного завода: Кирпичное (поле), Кирпичная (канава), Кирпичный (карьер). Там добывали глину светло-синего цвета, был построен кирпичный завод. Кирпичный карьер находился в районе Среднеостровского пролива.

За монастырскими стенами расположена на Валааме значительная по размерам площадь с рядом построек. Здесь просторно и нет лишней зелени. Это Хозяйственная площадь монастыря, на которой размещались кузница с мастерской, каретная, пекарня, пожарный сарай. На площади выделяется Рабочий конюшенный или Работный Аом, который имеет внутренний двор (1860-1871). Фасад главного корпуса с жилыми помещениями обращен к площади. К нему примыкают конюшни и мастерские. В этих корпусах находились помещения для хранения экипажей, пожарных инструментов, колесная, тележная и другие мастерские. На берегу Монастырской бухты в 1864 г. был построен Водопроводный дом с паровой машиной и водопровод. В трехэтажном здании Водопроводного дома находились монастырская прачечная, баня для братии и наемных рабочих, размещались кузница, столярная, слесарная, литейные мастерские. В 1865 г. был проложен водопровод и на территории монастыря, в жилые здания, больницу, гостиницу, конюшню, сады и огороды.

В самом названии площади «Хозяйственная» заключен главный принцип монастырской жизни: труд и молитва. Напротив возвышается Спасо-Преображенский собор, заключенный в два четырехугольника келейных корпусов, и рядом место, где выполнялись различные послушания, а между ними - Старое братское кладбище, по которому как связующее звено от послушания к молитве тянулись трубы водопровода к монастырю.

7) Банное хозяйство. В состав Валаамского архипелага входят Байевые острова, расположенные к востоку от Валаама. Это группа из девяти высоких покрытых лесом островов. Самым большим из всех островов является остров Байонной. Этот высокий с обрывистыми берегами остров имеет узкий перешеек шириной в 1 километр. Топонимы Баенной, Байенный, Байонной произошли от русского слова баня, которое произносилось как «байня», отсюда байенный, байенной. В словаре В. Ааля: «Баня байня, байна - паровая русская баня. Банный, баенный, байный - к бане относящийся» (Ааль, 1989: 45). На острове была построена баня для рыбаков, а так как на других островах бани не было, то этот остров стали называть Байенный, т. е. относящийся к бане.

8) Развитие туризма. Аля понимания внутренней жизни Валаамского монастыря, направленной на укрепление его экономики и благосостояния, следует учесть деятельность монастыря по развитию туризма на острове. Валаамский монастырь долгое время был недоступен для желающих увидеть святую землю. В середине XIX в. открылось регулярное пароходное сообщение по Аадожскому озеру. Валаамский монастырь начинает посещать особая группа людей - туристы отечественные и иностранные. В 1930-х годах, как показывает статистика, число туристов, посещавших монас- 
тырь, во много раз превышало паломников (НА РК. Ф. 762. Оп. 1. А. 14/162). Аля них была построена гостиница, которую называют Зимняя или Белая. Аля приема гостей в летний период было построено также деревянное здание $\Lambda$ етней гостиницы. На берегу Монастырской бухты стоял двухэтажный Странноприимный дом для бедняков. Паломников и туристов встречали на пристани в Монастырской бухте монах с повозкой для багажа и хор певчих, остальным монахам выходить за монастырские стены строго запрещалось. Всех приезжих в монастыре регистрировали, записывали в специальные «Паспортные книги».

В Зимней гостинице на стене у самого входа висел за стеклом монастырский Устав, обязательный как для богомольцев, так и для иноков. По статьям этого Устава без благословения о. игумена запрещалось входить инокам к богомольцам и даже богомольцам друг к другу. Как отмечает М. Шмелев, монах с суровым лицом проверял, как выполняется Устав гостиницы. Все нарушения он записывал в книгу (Шмелев, 1897: 98). Богомольцы, живущие на острове несколько дней, обязаны были выполнять различные послушания: работать в огородах, садах, мастерских. Свободные прогулки по острову запрещались.

В эти же годы в большом количестве приезжают в Валаамский монастырь и иностранные туристы из Германии, Швеции, Аании, Англии. На каждое лето монастырь нанимал переводчика для гостиницы, знающего финский, немецкий, шведский и другие языки. Постоянным монастырским гидом для иностранных туристов был также валаамский инок отец Памва.

На всех важных перекрестах были установлены на Валааме указатели с названиями на финском, английском, немецком и шведском языках: Во имя Всех Святых, церковь - All Saints church (на английском языке); Alla Helgons kyrka (на шведском языке); Die Kirche “Aller Heiligen” (на немецком языке); Kaikkien Pybien kirkko (на финском языке); Иерусалимскал, церковь, Новый Иерусалим - Die Jerusalem Kirche (на немецком языке); Jerusalemin kirkko (на финском языке); Jerusalems kyrka (на шведском языке); The church of Jerusalem (на английском языке); Uusi Jerusalemi (на финском языке); Гефсиманская, церковь - Getsemaneen kirkko (на финском языке); Getsemanes kyrka (на шведском языке); Die Getsemane kirche (на немецком языке); Church of Getbsemane (на английском языке); Елеон (Масленал, Масличная), гора Eleon (на финском языке); Mount of Olives (на английском языке); Oljeberg (на шведском языке); Oilymount (на английском языке); Ölberg (на немецком языке); Öljymäki (на финском языке).

Туристам также запрещалось свободное передвижение по острову, посещение скитов, но с разрешения о. игумена они могли получить у заведующего гостиницей лошадей с коляской, лодки с веслами и сопровождающего монаха, который давал путевую информацию и одновременно следил за тем, чтобы туристы не нарушали порядок. Так, например, желающих посетить Коневский скит привозили из монастыря на лодках по живописному озеру с маленькими островками и отвесными скалами. Тишину, покой и чувство полного уединения ощущал паломник в Коневском скиту. Казалось, что расположенный в глубине острова, окруженный со всех сторон лесом скит был всеми забыт. Размеренно текла здесь жизнь старцев, в трудах и молитвах.

Паломники и туристы, посещавшие Валаамский монастырь, не наносили ущерба Валааму. На острове запрещалось рубить деревья, охотиться на животных, нарушать покой птиц. Когда наступала осень, пароходы переставали ходить на Валаам. Закончив полевые работы, монахи приходили в мастерские, где выполняли различные 
послушания. Одни из них пекли хлеб, заготавливали дрова, другие работали в мастерских: столярной, слесарной, малярной, иконописной, шили обувь, одежду, работали в садах и в огородах, пели на клиросе и служили при церкви. «Послушание выше молитвы», - говорили монахи. Выше, но и труднее. Молитва — самое трудное по душевному усилию. Но послушание выше, потому что требует сломить свою волю. Надо сначала пройти долгий искус послушания, труда и работы, а уже потом открывается тебе область молитвы беспрепятственной. Поэтому и самые виды и роды работ называются«послушанием» (Нечаев, 1990).

\section{ИЗ ИСТОРИИ ВААААМА}

Название северного района Валаама Петровский (мыс, бухта, острова) появилось в 20-х годах XVIII в. и связано с героическими страницами Русского государства, участием и победой царя Петра I в Северной войне. Валаамский монастырь долгое время был порубежной землей на Русском Севере между Швецией и Россией. Шведы часто нападали на остров. В 1617 г. Россия вынуждена была заключить со шведами тяжелый для нее Столбовский мир, по условиям которого уступала Швеции Ижорскую землю с городами Ямь, Копорье, Ивангород, Карельский уезд с городом Корела (ныне г. Приозерск), в том числе и остров Валаам. В результате Северной войны (1700-1721) Россия вернула выход в Балтийское море, утраченные земли, принесла освобождение Валааму. Совершая поездки в Олонецкий край, государь Петр Великий не раз посещал Валаам и останавливался в северной части острова. В 1715 г. он издает указ о восстановлении Валаамского монастыря, приписанного к Кирилло-Белозерскому монастырю. После длительного запустения на Валааме вновь появилось монашеское население.

Топонимы военного времени. Аалее речь пойдет о топонимах, основанных на военной лексике: воинский, застава, оборона, полковник, сторож, стрельбище, штаб. Происхождение микротопонимов Стрельбище (район Валаама); Сторожевой (мыс); Оборонный (остров); Финская (застава); Финский (поселок) связаны с историческими событиями, происходившими на Валааме в годы Великой Отечественной войны. Южную группу островов Емельяновы называют также острова Оборонные. Остров Сухой получил название Оборонный. На этом острове и сейчас стоит железобетонная наблюдательная вышка, имеющая вид башни. В юго-восточной части острова находятся ряд военных укреплений, офицерский дом, столовая с кухней. На лежащих рядом островах размещался Финский поселок, встречаются оборонные укрепления и колючая проволока.

Природа Валаама. Помимо изучения истории Валаама и монастыря, необходимо остановиться на своеобразии его природы и особых климатических условиях, микроклимате, оказывающих влияние на все природное окружение островов Валаамского архипелага. Большое влияние на климат Валаама оказывает его расположение в районе наибольших глубин ( 233 м) Аадожского озера. На острове нет рек, но есть озера, которые монахи соединили каналами, глубоко вдающиеся фиорды. Тепло и высокая влажность создают эффект, благоприятный для растительного покрова и животного мира.

Более полное представление о природе Валаама мы можем создать, если обратимся к результатам нашего исследования топонимии русского происхождения, которое проводилось в 2000-2012 гг. и опубликовано в научных статьях и в монографии (Михайлова, 2013). В настоящем исследовании мы выстроим классификацию, включающую восемь семантических групп топонимов, отражающих физико-географические 
особенности местности и характеризующие объекты по размеру, форме, цвету, почве, особенностям растительного и животного мира Валаама.

1. Размер. Размеры характеризуют топонимы Малый, Большой: Большая Никоновская (бухта), Малая Никоновская (бухта), примыкающие к бухтам окрестности получили название Большое Никоновское (поле). Небольшой по размерам остров Ханхипаси, расположенный к юго-востоку от Валаама, был переименован в Малый, скит Всех Святых называли одновременно Большой (скит), а гора Скитская, находящаяся на острове, называется также Большая Скитская. Это действительно наивысшая точка вблизи Валаама, высотой 52 метра.

2. Цвет. Различный цвет географических объектов отражается в топонимах: Черный, Зеленый, Красный. Так, у северного берега Аадожского озера находится остров Большой Черный. Аанный топоним содержит две характеристики объекта: размер и цвет. В топонимии часто встречаются объекты с названием «Черный»: Черное море, Черная речка, мыс Черный у восточного берега Аадожского озера. Но это не значит, что объект имеет чисто черный цвет. К востоку от Валаама лежит очень высокий каменный остров Черный, покрытый густым хвойным лесом, издали вид его совершенно черный. Северо-восточный район Валаама характеризует топоним Черный Нос, здесь имеются непроходимые леса, которых почти не коснулась рука человека. В этом районе находится гора Черный Нос, высотой 36,3 метра, вторая по величине на Валааме. Мыс Черный Нос далеко вдается в Мадожское озеро. Нос в северном русском диалекте означает мыс. Черного цвета скала и мрачный лес на мысу, где почти не бывает солнца, отражается в бухте с названием Черная. Юго-западный мыс острова Валаам называется Красный, а южнее мыса расположен залив Красный. Мыс скалистый, в действительности имеет красноватый цвет. Такое впечатление создается за счет железа, входящего в состав габбро-диабаза, основной породы Валаама. Окисляясь на воздухе, железо приобретает красноватый цвет, характерный для скал Валаама. По этой же причине район в южной части острова Валаам называется Железняки, а залив - Железняковский. Железняки - это также второе название острова Емельяновский, севернее которого лежит остров с рыжевато-красной поверхностью, получивший название $\Lambda$ иса (Иисий). На восточном берегу бухты Осочной возвышается гора Железняковская. Мыс также каменный, красноватого цвета, что подтверждает наличие в породе железа. Юго-западный мыс острова Валаам, Красный, в 1919 г. получил название Красная Щель. Современное население Валаама незнакомо с большинством топонимов, местные жители пользуются в обиходе микротопонимами. Территория острова разделяется на различные районы: так, можно пойти к Белому скиту (скит Всех Святых), Желтому скиту (Гефсиманскому скиту), Красному скиту (Воскресенскому скиту).

3. Особенности почвы. Широкое распространение имеют также топонимы Каменный и Скалистый, например: мыс Каменный и остров Каменный у западного берега Аадожского озера. Второе название, Каменный, имеет также и северо-восточный мыс Валаама - Черный Нос. Остров Святой называют также Скалистый, Высокий, Угрюмый. В состав Валаамского архипелага входит остров Каменистый, северо-западнее которого находится остров Гранитный, самый большой из островов, расположенных у восточного берега Валаама. Южнее острова Гранитный лежит остров, лишенный растительности, с названиями Голый и Скалистый. К востоку от Валаама находится остров, имеющий довольно ровную поверхность и скудную растительность, это тоже остров Голый. Таким образом, исследование топонимов показало, что вдоль восточ- 
ного берега Валаама лежат небольшие каменистые со скудной растительностью или совершенно голые острова. Емельяновы острова, расположенные к югу от Валаама, также невысокие и имеют сглаженную ледником поверхность. И только остров Аевичий (Аивный) резко отличается своими размерами от других островов этой группы. Словно затерявшийся среди морских просторов огромный корабль, поднимается над маленькими голыми островками эта гигантская глыба с отвесными скалами и глубокими ущельями. Северо-восточная бухта острова Валаам называется Золотой Берег. В отличие от других скалистых районов острова, здесь имеется песчаный пляж. По этой же причине бухта Аосиный Берег получила второе название Песчаный Берег.

4. Внешнее сходство. Это топонимы, основанные на ландшафтной терминологии: гора, залив, озеро, бухта, канава, мыс, остров: Золотой Берег (бухта), Цосиный Берег (мыс), Залив к Белому (бухта), Владимирская Канава (канал).

Происхождение некоторых топонимов можно объяснить внешним сходством объекта с известными людям предметами. Так, три небольших каменных островка в группе Байевых островов имеют название Крюк. К югу от Валаама расположен лишенный растительности остров Яичный. Кроме этого, на берегу острова лежит круглый камень, похожий на куриное яйцо. В Монастырской бухте находятся два острова с похожими названиями Рыбачий и Рыбный. Остров Рыбный по форме похож на рыбу с длинным хвостом, а происхождение острова Рыбачий объясняется занятием людей на этом острове рыбалкой.

5. Расположение на местности. Эта группа получила названия по расположению

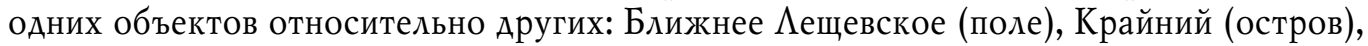
Нижний (остров), Противолежащий (остров). У западного берега $\Lambda$ адожского озера расположены мыс Аалекий и бухта Аалекая. К юго-востоку от Валаама лежит маленький островок Аадожский. Он назван так потому, что расположен в открытой части $\Lambda$ адожского озера, напротив «моря». То же самое можно сказать и о бухте $\Lambda$ адожской.

6. Аандшафтные топонимь. Это топонимы, основанные на ландшафтной терминологии: гора, залив, озеро, бухта, канава, мыс, остров: Золотой Берег (бухта), Һосиный Берег (мыс), Залив к Белому (бухта), Владимирская Канава (канал).

7. Флора. Природа Валаама уникальна. На острове встречается 470 видов растений, многие из которых редкие, 66 видов вошли в Красную книгу Карелии. На Валааме можно увидеть ландыш майский, перелеску благородную, купену душистую, касатик болотный. Нагретые солнцем скалы покрываются сиреневыми цветками тимьяна обыкновенного и белоснежными - камнеломки дернистой, желтыми пятнами очитка едкого. Среди охраняемых видов есть и лекарственные растения: зверобой продырявленный, валериана бузинолистная.

Большая группа топонимов связана с растительным миром. Некоторые острова в $\Lambda$ адожском озере называются Сосновыми, так как преобладающим типом растительности на этих островах является сосна. Так, остров Сосна (Сосновый) входит в группу Емельяновых островов, также остров Сосновый расположен у северного берега Аадожского озера. Остров Сосновец лежит напротив Валаама, к востоку от острова Черный. На острове Осиновый, восточнее Никольского острова, преобладающим типом растительности является осина. В Ольховой бухте на Ольховом мысе растет ольха. ОАно из многочисленных названий острова Святого - Яблоневый, так как на острове был посажен монахами яблоневый сад. Острова в Большой Никоновской бухте, на которых монахи сеяли рожь и овес, были названы Ржаной и Овсяный. Там 
же находится и остров Ягодный. Севернее острова Гранитный, отделенный от него узким проходом глубиной 2,4 метра, лежит маленький каменный остров Ауковый, на котором растет лук-резанец. В южной части Валаама находится бухта Осочная, в восточной части - бухта Тростяная. Все эти названия даны также по типу растительности. Топоним Тростяной имеет также восточный мыс Валаама и один из его восточных районов. Из монастыря в Тростяное была проложена в 1841 г. одна из самых первых дорог на острове.

8. Фауна. Чаще всего увидеть, а точнее - услышать на Валааме можно птиц, которых насчитывается около 90 видов: зяблик, зарянка, чиж, пеночка, певчий дрозд. Среди млекопитающих встречаются лось, белка, горностай, куница, заяц-беляк, лисица. Крупных хищников на Валааме нет. Сказывается удаленность острова от материка. В зимнее время, однако, были отмечены случаи захода на остров волка, рыси. В некоторых источниках упоминается о наличии на острове оленей. Есть упоминание об этом и в монастырских книгах. «Случается инокам наезжать на целое стадо оленей, стоящее где-нибудь на дороге, и эти кроткие животные спокойно, без страха, разойдутся по сторонам, посмотрят на проезжающих, дадут им проехать и потом снова соединятся в свое стадо», - вспоминали монастырские жители (Валаамский монастырь, 1864: 10). Возможно, восточный мыс Валаама, названный Олений, был основным местом их обитания. Камни и скалы островов являются удобным местом обитания пресмыкающихся, среди которых опасна для человека гадюка обыкновенная.

Знакомство с топонимами, включающими лексемы: гагара, лещ, налим, сиг, заяц, чайка, сорока, угорь и др., дополнит наше представление о животном мире Валаама:

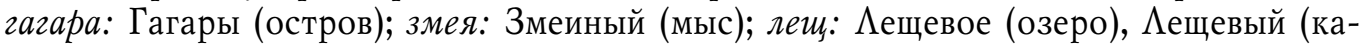

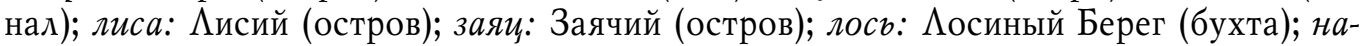
лим: Налимий (остров); олень: Олений (мыс); сорока: Сорокины (луды); угорь: Угревая (бухта) и др.

Таким образом, Валаам как памятник культуры представляет универсальную ценность. Здесь сложилась уникальная сеть ландшафтно-парково-архитектурных комплексов, где удачно сочетаются дикая природа, садово-парковые ансамбли, строения и сооружения культового, хозяйственного и бытового назначения.

\section{СОАОВЕЦКИЙ МОНАСТЫРЬ}

Следующим шагом нашего исследования будет изучение семантики и структуры компонентов топонимов, характеризующих хозяйственно-экономическую деятельность Соловецкого Спасо-Преображенского монастыря. Аля решения данной задачи мы выстроим классификацию топонимов островов Соловецкого архипелага, выявленных автором в ходе полевых, архивных и других исследований на островах Соловецкого архипелага в 2012-2015 гг. (Михайлова, 2015). Настоящая классификация топонимов более полно отражает различные виды деятельности Соловецкого монастыря, его историю и природу и публикуется впервые. По ходу исследования мы дадим также описание объектов, расположенных в центральном монастырском ансамбле и за монастырской стеной как на Большом Соловецком острове, так и на других островах архипелага.

Центральный монастырский ансамбль. Центром Соловецкого монастырского комплекса является кремль, расположенный на узком перешейке между озером Святое и морским заливом, бухтой Благополучия на западном берегу Большого Соловецкого острова. Ауховное и материальное бытие кремля имеет замкнутое пространст- 
во, сосредоточенное на небольшой площади в форме неправильного пятиугольника и закрытой от мирской жизни мощной крепостной стеной с восемью башнями. Монастырский ансамбль состоит из культовых, хозяйственных и жилых корпусов, каждый из которых имеет свое название. Территория делится на три части: Центральный двор, Северный двор и Южный двор. В Центральном дворе находятся Спасо-Преображенский собор, Успенская церковь, церковь свт. Николая Чудотворца, Свято-Троицкий Зосимо-Савватиевский собор, которые с южной, западной и северной сторон окружают келейные корпуса: Братский больничный и Святительский, расположенные на южной стороне; на северной линии находятся корпуса: Благовещенский, Настоятельский, Келейный, Казначейский, к северу построен Наместнический корпус с кельями. Через Спасские ворота можно выйти в Северный двор, имеющий хозяйственное назначение, что отражено в названиях расположенных здесь зданий XVI-XVII вв.: Рухлядная (палата), Портная и Чоботная (палаты), Кожевенная (кладовая), Столярные (мастерские), Рыбный (амбар).

Монастьрское хозяйство. Расцвет Соловецкого монастыря в XVI в. связан с деятельностью игумена Филиппа (в миру Федор Колычев, впоследствии митрополит Московский и всея Руси), обладающего исключительными для своего времени знаниями и проявившего себя не только как духовный наставник обители, но и как грамотный талантливый инженер. Монастырь и его хозяйство стали главным делом всей жизни Филиппа Колычева. За 18 лет игуменства Филиппа монастырь превратился в техническое чудо своего времени. Самым грандиозным сооружением игумена Филиппа считается устройство на Соловках канальных систем, соединивших в то время 52 озера. Первоначально по велению св. Филиппа несколько десятков соловецких озер были соединены каналами, из которых вода поступала в Святое озеро, а из него по Мельничному каналу в Южном дворе шла к мельнице, которая не только молола и толкла зерно, но и стирала белье в специальном устройстве «Портомойне». Выложенный из булыжника подземный канал является редким гидротехническим сооружением, протянувшимся более чем на 100 метров из Святого озера в морскую бухту.

При игумене Филиппе прокладываются дороги, на Большом Заяцком острове была возведена самая старая из сохранившихся в России каменная гавань. Но особенно прославился игумен каменным строительством монастыря, который до XVI в. был деревянным и в 1485, 1538 гг. был почти полностью уничтожен пожаром. Уникальным сооружением игумена Филиппа является одностолпная Трапезная палата (483 кв. м), возведением которой руководили мастера из Великого Новгорода. Главным духовным центром Соловецкого монастыря является построенный за восемь лет (1558-1566) игуменом Филиппом новый каменный Спасо-Преображенский собор, который также возводили новгородские строители. В монастыре были свои мастерские и заводы: Водопроводная мастерская, Месопильный завод, Кожевенный завод, Смолокурня, Канатный завод; Кирпичный завод, Алебастровый завод, Водорослевой комбинат, Воскобелильный завод; Гончарный завод, Парники-оранжереи; действовали различные службы: Монастырская метеостанция, Монастырская радиостанция.

Топонимы характеризуют также различные направления обширного хозяйства Соловецкого монастыря: животноводческое, солеварение, промыслы.

1. Солеварение. О занятии Соловецкого монастыря солеварением известно из сохранившихся названий с лексемой «соль», например: усолье - место, где занимались 
вываркой соли. Монастырю принадлежали 54 варницы на Беломорье, где было занято более 1000 рабочих. На Большом Соловецком острове находилось строение для хранения соли - Соляной амбар. На острове Анзер размещалось Монастырское Усолье, Солеварни, где около 70 человек занималось солеварением. Царь Иван IV увеличил размер монастырских льгот для продажи соли до 10 тыс. пудов, 160 тонн, и подарил монастырю 26 сел, в которых были 33 соляные варницы. Таким образом, при игумене Филиппе соль стала основным источникам дохода монастыря.

2. Животноводство. О хозяйственной деятельности Соловецкого монастыря, направленной на развитие животноводства, рассказывают топонимы: Кобылья (губа); Сенные Ауды (острова). В монастырском хозяйстве был свой Конный двор, Птичий двор; сараи: Каретный, Скотный, Фуражный; амбары: Фуражный, Хлебный. Строгий устав Соловецкого монастыря запрещал держать рядом с обителью живородящую скотину. Игумен Филипп ввел запрет разводить около монастырских стен «живородящую скотину» (Кодола, 2012: 31). Надо сказать, что в духовных традициях северных православных монастырей было принято устраивать молочное хозяйство вдали от монастырского центра. Так, например, в Валаамском монастыре молочную ферму от центрального монастырского комплекса отделяет водное пространство Монастырской бухты и Среднеостровского озера, между которыми расположен остров Скитский. Русские православные монастыри соблюдали духовные традиции Афона, где разрешалось содержать в монастыре животных только мужской особи, за исключением птиц и диких животных. Животноводческое хозяйство Соловецкого монастыря находилось в основном на острове Большая Муксалма, где, еще в XVI в., при игумене Филиппе была устроена Монастырская Ферма (Коровий Авор). Обширные луга острова служили пастбищами для монастырского стада. На острове Анзер были также устроены Млечный Аом, Скотный Авор и ряд других хозяйственных построек.

3. Гостиничное хозяйство. Гостиничное хозяйство монастыря характеризуют топонимы с лексемами: трудник, паломник, корпус, гостиница, изба, женская, бабья.

Экономика монастыря и его обширное хозяйство строились и развивались не только трудами монашествующих, но и с помощью значительного количества паломников и трудников, приезжавших на разные сроки, иногда на несколько лет, в Соловецкий монастырь. Некоторые из них принимали постриг и оставались в монастыре. В монастыре благожелательно относились к паломникам и трудникам, для проживания которых на островах были построены специальные здания, это различные корпуса: для работников и братии, для годовиков; для паломников и трудников. Кроме этого, были дома и избы: Жилая изба для кузнецов и трудников и др. Аля проживания паломников на Соловецких островах строятся гостиницы Архангельская (Аеревянная), Петербургская, Преображенская и дома для приезжих. Топонимы Бабий, Бабья Ауда (ср. финск. luoto «подводная скала, риф»), объясняет размещение на острове женщин-паломниц, которым первоначально не разрешалось проживать на Большом Соловецком острове, рядом с кремлем, куда на службу их переправляли в специальных лодках. Встречаются также и другие названия острова: Женская гостиница; Гостиница на острове Бабий.

Аля женщин, приезжавших на богомолье, на южном берегу бухты Благополучия была построена в 1836 г. деревянная двухэтажная гостиница Архангельская. На противоположном берегу бухты стоит трехэтажная каменная Преображенская гостиница, куда селили состоятельных паломников. В Петербургской гостинице, располо- 
женной на пригорке напротив Корожной башни, останавливались небогатые паломники. Суда с паломниками, купцами, путешественниками прибывали в бухту Благополучия к пристани с названием Царская, расположенной напротив Святых ворот. В конце XIX в. рядом с Преображенской гостиницей был построен причал Новый Монастырский. Название бухты - Благополучия, на берегу которой стоит Соловецкий кремль, завораживает, настраивает нас на добро, на чудо, на встречу с прекрасным (ср. Благо - «добро», Благодать - «дать добро: любовь, милость, благодеяние», Благополучие - «получить добро, помощь, любовь»), следовательно, бухта Благополучия и Соловецкий монастырь являются тем самым местом, где путника ожидает Благодать: «любовь, милость и помощь, ниспосланная свыше».

4. Банное хозяйство. Топонимы Банное (озеро), Малое Банное (озеро), Большое Банное (озеро) указывают на имеющееся в монастыре банное хозяйство. В XVII в. на западном берегу озера Гагарье (Банное) было построено каменное здание бани Монастырской, рядом стояла деревянная изба Портомойная и деревянная баня Мирская. Баня Белецкая (Валунная) предназначалась для трудников монастыря - «бельцов». «Чернецы», монахи, мылись в отдельной бане, расположенной в Южном дворе кремля. В каждом скиту была также своя Валунная баня.

5. Морское хозяйство. Монастырское морское хозяйство состояло из различных служб, обеспечивавших промысловую деятельность монастыря, обработку и хранение различной продукции. Аля этого на берегу бухты Благополучия, а также в скитах были построены специальные сооружения, амбары и погреба для засаливания и хранения рыбы: Сальный (амбар); Погреб (для хранения сала морских животных); Промысловые (избы); Погреб-ледник; Амбар (для обработки кожи); Сельдяной (амбар); Рыбная (изба) и др.

6. Рыболовство. Издавна главным для Соловецкого монастыря был рыбный промысел. Часто из-за ненастной погоды рыбаки не могли выйти в море на ловлю рыбы. B XVI в. один из заливов был отделен от моря каменной дамбой и назван «Филипповские садки» в честь инициатора их устройства игумена Филиппа Колычева. Это уникальное сооружение, где разводили и содержали выловленную в море рыбу, которую доставляли в монастырь к столу. Садки располагались по берегу моря и отделялись от него валунными дамбами, через которые происходила фильтрация морской воды (Скопин, 2008: 174-175). Излишки живой пойманной рыбы (сельди, трески) выпускались в садки, где она росла и размножалась и откуда монахи могли ловить рыбу в любую погоду.

С западной стороны бухты Благополучия расположен узкий мыс с названием Сельдяной, к небольшой пристани которого подходили рыболовные суда и отгружали свою добычу. Здесь находились здания, связанные с морским хозяйством обители, промыслом морских животных: Такелажный амбар, Погреб для хранения сала морских животных, которое использовалось для технических целей. Улов соловецкой селедки доставляли в монастырь через Рыбные (Сельдяные) ворота на западной линии Монастырской стены. В каждом становище имелись примитивные, кустарного типа заводы для перетапливания рыбьего жира. Эти заводы называются салогрейкой или салотопней, например: Салотопенный Завод (Салотопня) на Большом Соловецком острове и на острове Анзер.

7. Промысль. С рыболовным промыслом Соловецкого монастыря связаны многочисленные промысловые тони, урочища, стамики, становища, ловища, расположенные как на Большом Соловецком острове, так и на других островах Соловецкого ар- 
хипелага. Это Садки (для рыбы), ловище Трещанское, урочища с названиями: Белужье, Большое Куликово, Варварка, Городки, Аамба, Капорское и др. монастыря имеют топонимы: Безымянная, Березова, Горелая, Кирилловская, Филимонова и др.

Промысловые тони (ср. тоня - «небольшие заливчики в губе моря, где обычно наблюдается скопление рыбы в промысловые сезоны года») имеют топонимы: Безымянная, Березова (Березовая, Березовская), Горелая, Кирилловская, Овсянка, Филимонова и др. Монастырские становища (ср. становище - «рыбацкий промысловый поселок») были расположены в местах с названиями: Нерпичья, Овсянка, Реболда. На промысловую деятельность монастыря указывают также топонимы: Белужье (тоня, урочище), Белужий (мыс), Белужья (губа); Нерпичья (губа, становище, тоня), Промысловое (озеро), Тюленье (озеро), Становое (озеро), Большое Охочье (озеро).

8. Монастырский флот. Торгово-промысловый флот Соловецкого монастыря со Средневековья и до начала ХХ в. являлся крупнейшим на Русском Севере. В Бухте Благополучия размещалась Карбасная служба (ср. карбас, от баркас - «гребное судно для речного и прибрежного морского промысла длиной от 3 до 6,5 метра»), состоящая из различных сараев, Погреба для смоления канатов, Амбара для хранения гребных судов и орудий лова. Рядом с монастырской стеной находится док с названием Сухой. Аля его устройства в XVI в. был прорыт крепостной ров, который заполнялся водой из Святого озера, переделанный позднее в подземный канал Вешняк. Сухой док (Морской) был собственным изобретением соловецких монахов. Здесь ремонтировали суда монастырского флота, он использовался также и как судостроительная верфь.

Таким образом, в XVI-XVIII вв. практически все Поморье находилось под экономическим влиянием Соловецкого монастыря, который владел богатейшими рыбными, звериными и соляными вотчинами по всем берегам Белого моря.

Топонимы военного времени. Топонимы военного времени составляют особую группу, характеризующую как деятельность Соловецкого монастыря на различных исторических этапах, так и в советский период в истории государства и Соловков. Все топонимы можно объединить в две группы.

1-я группа. Это топонимы, описывающие объекты времен Великой Отечественной войны: Учебный отряд Северного флота; Земляная Батарея; Оборонительные Сооружения; Соловецкая Школа Юнг. На островах Соловецкого архипелага и сегодня можно увидеть траншеи и оборонительные сооружения 40-60-х годов XX в., созданные бойцами Учебного отряда Северного флота (УО СФ), например на мысе Восточный Печак Большого Соловецкого острова.

2-я групnа. К данной группе относятся топонимы, характеризующие лагерный период истории Соловецкого монастыря. Это названия объектов, которые не только хранят память о тяжелом и трагичном для всей страны времени, но и сами являются памятниками новой истории как Соловецкого монастыря, так и нашего государства. 3десь также можно выделить несколько групп топонимов:

1. САОН. Многие названия, как печать на страницах истории, содержат аббревиатурное имя «С $\Lambda \mathrm{OH}$ » (Соловецкий лагерь особого назначения): Рабочий Городок

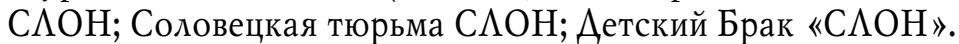

2. Тюрьма. Ряд названий напоминают нам о расправах над людьми, совершаемых в Соловецкой тюрьме: Братские Могилы Узников С $\Lambda \mathrm{OH}$, Аагерное кладбище С $\Lambda \mathrm{OH}$ (Филимоново); Аестница (на горе Секирная) и др. 


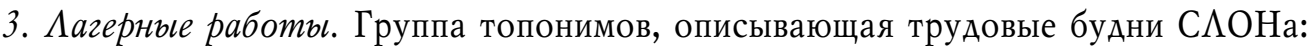
Торфогородок; Кирпзавод, Аагпункт; Узкоколейная железная дорога (Порт - Кирпзавод - Торфоразработки, 1925-1931 гг.).

4. Бинарность объектов. Аанная группа топонимов включает названия культовых объектов Соловецкого монастыря, которые использовались для содержания заключенных, например: скит Секиро-Вознесенский, церковь Вознесенская - Штрафной изолятор $\mathrm{C} \Lambda \mathrm{OH}$, Соловецкий монастырь - Соловецкая тюрьма и др.

В советское время некоторые объекты на Соловецких островах были переименованы и получили новые названия. Озеро Белое стали называть Красное; Большое Белое Большое Красное; Большое Исаинское - Большое Торфяное.

Архитектурно-ландшафтные комплексы Соловецкого монастыря составляют духовное, историческое и культурное богатство Русского Севера, они включены в список Всемирного наследия ЮНЕСКО.

\section{СРАВНИТЕАЬНЫЙ АНАИИЗ СЕМИОТИЧЕСКОГО ПРОСТРАНСТВА ВААААМСКОГО И СОАОВЕЦКОГО АРХИПЕААГОВ}

Семиотическое пространство Соловков и Валаама объединяют их островное положение и деятельность православных монастырей, имеющих одинаковое название: Спасо-Преображенский ставропигиальный мужской монастырь с главным храмом Спасо-Преображенским собором. По утверждению Н. М. Теребихина, образ Преображения играл в символике островных монастырей Русского Севера (Валаамского и Соловецкого), соборные храмы которых были возведены во имя праздника Преображения Господня, особо значимую роль (Теребихин, 2004: 30).

Топонимы Валаамского и Соловецкого архипелагов во многом идентичны, так как в них отражается хозяйственно-экономическая деятельность монастырей, направленная на укрепление монастырского хозяйства и создание условий для развития духовной жизни иноков. Так, к топонимам, описывающим хозяйство Соловецкого монастыря, относятся: Кожевенная (кладовая), Рыбный (амбар), Мельничный (канал), Святое (озеро), Водопроводная (мастерская), Кирпичный (завод), Садки (озеро) и др., подобные названия объектов встречаются и на территории Валаамского монастыря: Берег Кожевенного Завода (бухта), Рыбный (остров), Мельничная (бухта), Святой (остров), Водопроводный (дом), Кирпичный (завод), Садковый (остров). С участием и победой царя Петра I в Северной войне связано название северного района Валаама - Петровский (мыс, бухта, острова), на Анзерском острове также сохранился объект с топонимом Городок Петра Великого (Соловецкий архипелаг).

На специфику хозяйственной деятельности Соловецкого монастыря указывают названия: Водорослевой (комбинат), Промысловые (урочища), Белужье (тоня, урочище), Нерпичья, (губа, становище, тоня), Карбасная (служба). Развитие иностранного туризма на Валааме в начале $\mathrm{XX}$ в., в отличие от Соловков, подтверждают топонимы на английском, немецком, шведском, финском языках: Елеон (гора) - Mount of Olives (на английском языке); Oljeberg (на шведском языке); Ölberg (на немецком языке); Öljymäki (на финском языке).

Основные различия имеют ландшафтные топонимы, характеризующие флору и фауну, а также природные объекты, расположенные на островах Валаамского и Соловецкого архипелагов. Сравнивая ландшафтные топонимы, мы можем сделать вывод о характерных для данных локусов представителях флоры и фауны. Так, например, на островах встречаются названия с одинаковыми лексемами: гагара: Гагары (остров) (Ba- 
лаамский архипелаг); Гагарье (озеро), (остров Соловецкий); заяч: Заячий (остров) (Валаамский архипелаг); Большой Заяцкий (остров), Заяцкая (мель), Малый Заяцкий (остров) (Соловецкий архипелаг); чайка: Чаячьи (острова) (Валаамский архипелаг); Чайка (озеро) (остров Соловецкий); шука: Щучье (озеро) (Валаамский архипелаг); Щучье (озеро) (остров Соловецкий); береза: Березовый (мыс), Березовый (остров) (Валаамский архипелаг); Березовое (озеро) (остров Соловецкий); сосна: Сосновый (остров) (Валаамский архипелаг); Сосновая (губа), Сосновое (озеро) (остров Соловецкий); ягода: Ягодный (остров) (Валаамский архипелаг); Ягодное (озеро) (остров Соловецкий).

Различие флоры и фауны Валаамских и Соловецких островов подтверждает факт отсутствия тех или иных ландшафтных топонимов на их территории. Так, в топонимии Валаамского архипелага не встречаются соловецкие топонимы с такими лексемами, как баран, белуха, волк, дрозд, журавль, карась, кулик, лебедь, морошка, мох, нерпа, орел, пичуга, плотва, сельдь, треска, тюлень. Среди ландшафтных топонимов Соловецкого архипелага отсутствуют названия с лексемами, характерными для Валаамской топонимии: змея, лещ, лось, налим, олень, петух, сиг, сорока, угорь, дуб, горох, лук, ольха, осина, осока, рожь, троста, тростник, турнепс, черника, яблоня.

Исследование топонимии островов Валаамского и Соловецкого архипелагов показало лишь частичное совпадение названий географических объектов, например: Красный (мыс), Крестовое (озеро), Монастырская (дорога). В основном подобные топонимы относятся к разным объектам: Святое (озеро), Каменное (озеро), Грязная (губа); Железные Ворота (пролив), Аолгая губа (губа), Игуменский (остров) (Соловецкий архипелаг); Святой (остров), Каменная (гора), Грязное (озеро), Железные ворота (гора), Аолгой (луг), Игуменское (озеро) (Валаамский архипелаг).

\section{ЗАКАЮЧЕНИЕ}

Подводя итоги, отметим, что семиотическое пространство Русского Севера характеризуют названия природных объектов, расположенных на островах Валаамского и Соловецкого архипелагов, а также топонимы, описывающие культурное пространство, хозяйственно-экономическую деятельность Спасо-Преображенских монастырей:

- характеристика объектов (размер, форма, цвет, особенности почвы и т. п.): Большое Никоновское (поле); Большая Скитская (гора); Глинистая (бухта); Скалистая (бухта); Черное (озеро); Красная (бухта) и др. (Валаамский архипелаг); Большая Муксалма (остров); Малая Муксалма (остров); Белое (Красное) (озеро); Большое Каменное (озеро); Болотное (озеро); Каменное (озеро); Моховое (озеро); Красная (губа) (Соловецкий архипелаг);

- отантропонимные наименования, связанные с именами мирских жителей, выдающихся посетителей Валаама (царей, художников и др.): Беланов (хутор); Петровская (бухта); Шишкинская (сосна) (Валаамский архипелаг); Камень А. С. Аихачева, 1931 г. (памятное место); Царская (пристань); Павла Флоренского (мыс); Городок Петра I (булыжная насыпь) (Соловецкий архипелаг);

- виды хозяйственной деятельности монастыря: Бредневый (остров); Выволок (мыс); Старозаводской (залив); Неводная (бухта) (Валаамский архипелаг); Кирилловская Тоня (урочище); Озерно-канальная (система); Банное (озеро); Сельдяной (мыс), полуостров (Соловецкий архипелаг);

- топонимы, основанные на военной лексике: Оборонные (острова); Полковницкое (поле); Сторожевой (остров) (Валаамский архипелаг); Кирпзавод, лагерный пункт $\mathrm{C \Lambda OH} \mathrm{( \Lambda агпункт,} \mathrm{Кирпичный} \mathrm{завод);} \mathrm{Огневая} \mathrm{позиция} \mathrm{Учебного} \mathrm{отряда} \mathrm{Северного}$ 
флота (УО СФ), с окопами и деревоземляными огневыми точками (дзотами) (гора Фавор, 40-е годы); Переговорный Камень (памятное место) (Соловецкий архипелаг);

- микротопонимы: Глухое (озеро); Красный (скит); Турнепсовое (поле) (Валаамский архипелаг); Хутор Горка (поселок); Царское Село (район); Большое Комсомольское (озеро) (Соловецкий архипелаг).

Следовательно, созданные разными поколениями людей, топонимы раскрывают гармонию рукотворного и природного ландшафтов, дополняют культурный образ монастырей Русского Севера.

\section{СПИСОК АИТЕРАТУРЫ}

Бахтин, М. М. (1979) К методологии гуманитарных наук // Эстетика словесного творчества / сост. С. Г. Бочаров. М. : Искусство. 424 с. С. 361-373.

Валаамский монастырь (1864) СПб. : Тип. Аепартамента уделов. 348 с.

Ааль, В.И.(1989) Толковый словарь живого великорусского языка : в 4 т. М. : Русский язык, T. $1.699 \mathrm{c}$.

Кассирер, Э. (1993) Эссе о человеке. Введение в философию человеческой культуры // Вестник Московского университета. Сер. 7 Философия. № 1. С. 3-26.

Керт, Г. М. (2009) Саамская топонимная лексика. Петрозаводск : Карельский научный центр PAH. 178 c.

Кодола, О. Е. (2012) Федор Колычев - дитя эпохи. Архангельск : ООО «Поморский сувенир». 69 c.

Аосев, А. Ф. (1990) Философия имени // Аосев, А. Ф. Из ранних произведений. М. : Правда. 655 c. C. $24-186$.

Иотман, Ю. М. (1993) О семиотическом механизме культуры // Иотман, Ю. М. Избранные статьи : в 3 т. Таллин : Александра. Т. 3.495 с. С. 328-329.

Марков, Б. В. (2001) Знаки бытия. СПб. : Наука. 554 с.

Матонин, В.Н.(2013) «Наше море - наше поле». Социокультурное пространство северной деревни: генезис, структура, семантика. Архангельск : ИПЦ САФУ. 334 с.

Мелютина, М.Н., Попова, $\Lambda$. А., Теребихин, Н. М. (2015) Сакральная география и иеротопия Русского Севера. Архангельск : СО АТИ. 231 с.

Мечковская, Н. Б. (1998) Язык и религия. М. : Агенство «Фаир». 252 с.

Михайлова, $\Lambda$. В. (2012) Валаам в географических названиях. Топонимическая карта. Петрозаводск : ООО «Издательство «Острова». 8 с. : ил.

Михайлова, А. В. (2013) Валаам: Град Земной - Град Небесный. Петрозаводск : Изд-во КГПА. 180 с.

Михайлова, $\Lambda$. В. (2015) Преображение Русского Севера. Петрозаводск : ИзА-во ПетрГУ. $112 \mathrm{c}$.

Нечаев, А. И. (1990) Старый Валаам // Русский паломник. № 2. С. 105-114.

Скопин, В. В. (2008) На Соловецких островах. М. : АСТ ; Астрель ; Хранитель. 255 с.

Теребихин, Н. М. (2004) Метафизика Севера. Архангельск : Поморский государственный университет имени М. В. Аомоносова. 271 с.

Теребихин, Н. М. (1993) Сакральная география Русского Севера (Религиозно-мифологическое пространство севернорусской культуры). Архангельск : Издательство Поморского международного педагогического университета имени М. В. Аомоносова. 223 с.

Флоренский, П. А. (1990) Имеславие как философская предпосылка // Флоренский, П. А. Сочинения : в 2 т. М. : Правда. Т. 2.447 с. С. 281-321.

Фрейденберг, О. М. (1998) Миф и литература древности. М. : Издательская фирма «Восточная литература» РАН. 894 c.

Шмелев, И. С. (1897) На скалах Валаама (путевые очерки). М. : Тип. Е. Гербек. 61 с. 


\section{V. MIKHAILOVA \\ Petrozavodsk State University}

The semiotic space of the Russian North culture includes the Valaam and Solovetsky archipelagos, as well as toponyms characterizing the spiritual and material existence of the Transfiguration monasteries, natural objects, flora and fauna of the region. The relevance of the research is conditioned by an increasing interest in spiritually moral, historically cultural and landscape space of the Russian North, the spirituality of which is determined by the fundamental role of the Solovetsky and Valaam Orthodox monasteries. The aim of this article is to determine the cultural and historical, toponymical, and landscape spaces of the Russian North. The research tasks are to correlate the spiritual culture of northern monasteries with the material and natural culture of the Russian North; to educe the role of the mundane names of Valaam and Solovetsky monasteries' cultural landscapes.

The article presents the results of an empiric research of the geocultural space of the Valaam and Solovetsky monasteries. In order to determine the Solovki and Valaam semiotic space the following methods are used: collection of information, linguistic analysis of the names of the geographical objects located on the islands of Valaam and Solovetsky archipelagos discovered during field research and from different sources; the synthesis of different approaches: philosophical, historical, geographical, religious, and literary. The study of the Valaam toponymy of Russian origin was conducted in 2000-2012 and published in scientific articles and in the monograph «Valaam: The City of Earth The City of Heaven» (Mikhailova, 2013). In this article the classification of toponyms characterizing the Valaam nature is published for the first time. The next step of our research is the study of the semantics and structure of toponym components characterizing the economic activity of the Solovetsky monastery. Field, archival and other studies were carried out by the author on the Solovetsky archipelago islands in 2012-2016 and published in scientific articles and in the monograph «Transfiguration of the Russian North» (Mikhailova, 2015). The toponyms classification of the Solovetsky archipelago islands, presented in this article, reflects various activities of the Solovetsky monastery, its history and nature more fully. Based on the collected toponymic material, the author also conducts a comparative analysis of the Solovki and Valaam semiotic space for the first time.

The semiotic space of the Russian North is characterized by the names of the natural objects located on the Valaam and Solovetky archipelagos islands, and the toponyms describing the cultural space, as well as economic and household activity of the Transfiguration monasteries. The toponyms created by different generations of people reveal the harmony of the handmade and natural landscapes, complement the cultural character of the Russian North monasteries.

Keywords: Valaam; Solovki; semiotic space; sign system; monastery; cultural and landscape complex; toponym; Russian North

\section{REFERENCES}

Bakhtin, M. M. (1979) K metodologii gumanitarnykh nauk. In: Estetika slovesnogo tvorchestva/ comp. by S. G. Bocharov. Moscow, Iskusstvo. 424 p. Pp. 361-373. (In Russ.).

Valaamskii monastyr' (1864). St. Petersburg, Tip. Departamenta udelov. 348 p. (In Russ.).

Dal', V. I. (1989) Tolkovyi slovar' zhivogo velikorusskogo iazyka: in 4 vol. Moscow, Russkii iazyk. Vol. 1.699 p. (In Russ.).

Kassirer, E. (1993) Esse o cheloveke. Vvedenie v filosofiiu chelovecheskoi kul'tury. Vestnik Moskovskogo universiteta, issue 7, Filosofiia, no. 1, pp. 3?26. (In Russ.).

Kert, G. M. (2009) Saamskaia toponimnaia leksika. Petrozavodsk, Karel'skii nauchnyi tsentr RAN. 178 p. (In Russ.).

Kodola, O. E. (2012) Fedor Kolychev - ditia epokbi. Arkhangel'sk, OOO «Pomorskii suvenir». 69 p. (In Russ.).

Losev, A. F. (1990) Filosofiia imeni. In: Losev, A. F. Iz rannikb proizvedenii. Moscow, Pravda. 655 p. Pp. 24-186. (In Russ.).

Lotman, Iu. M. (1993) O semioticheskom mekhanizme kul'tury. In: Lotman, Iu. M. Izbrannye stat' $i$ : in 3 vol. Tallin, Aleksandra. Vol. 3. 495 p. Pp. 328-329. (In Russ.). 
Markov, B. V. (2001) Znaki bytiia. St. Petersburg, Nauka. 554 p. (In Russ.).

Matonin, V. N. (2013) "Nashe more - nashe pole». Sotsiokul' turnoe prostranstvo severnoi derevni: genezis, struktura, semantika. Arkhangel'sk, IPTs SAFU. 334 p. (In Russ.).

Meliutina, M. N., Popova, L. D. and Terebikhin, N. M. (2015) Sakral'naia geografiia i ierotopiia Russkogo Severa. Arkhangel'sk, SOLTI. 231 p. (In Russ.).

Mechkovskaia, N. B. (1998) Iazyk i religiia. Moscow, Agenstvo «Fair». 252 p. (In Russ.).

Mikhailova, L. V. (2012) Valaam v geograficheskikb nazvaniiakb. Toponimicheskaia karta. Petrozavodsk, OOO «Izdatel'stvo «Ostrova». 8 p. (In Russ.).

Mikhailova, L. V. (2013) Valaam: Grad Zemnoi - Grad Nebesnyi. Petrozavodsk, Izdatel'stvo KGPA. 180 p. (In Russ.).

Mikhailova, L. V. (2015) Preobrazhenie Russkogo Severa. Petrozavodsk, Izd-vo PetrGU. 112 p. (In Russ.).

Nechaev, A. I. (1990) Staryi Valaam. Russkii palomnik, no. 2, pp. 105?114. (In Russ.). Russ.).

Skopin, V. V. (2008) Na Solovetskikh ostrovakh. Moscow, AST; Astrel'; Khranitel'. 255 p. (In

Terebikhin, N. M. (2004) Metafizika Severa. Arkhangel'sk, Pomorskii gosudarstvennyi universitet imeni M. V. Lomonosova. 271 p. (In Russ.).

Terebikhin, N. M. (1993) Sakral'naia geografiia Russkogo Severa (Religiozno-mifologicheskoe prostranstvo severnorusskoi kul'tury). Arkhangel'sk, Izdatel'stvo Pomorskogo mezhdunarodnogo pedagogicheskogo universiteta imeni M. V. Lomonosova. 223 p. (In Russ.).

Florenskii, P. A. (1990) Imeslavie kak filosofskaia predposylka. In: Florenskii, P. A. Sochineniia: in 2 vol. Moscow, Pravda. Vol. 2. 447 p. Pp. 281-321. (In Russ.).

Freidenberg, O. M. (1998) Mif i literatura drevnosti. Moscow, Izdatel'skaia firma «Vostochnaia literatura» RAN. 894 p. (In Russ.). Russ.).

Shmelev, I. S. (1897) Na skalakb Valaama (putevye ocherki). Moscow, Tip. E. Gerbek. 61 p. (In

Submission date: 10.01.2017.

Михайлова Аариса Владимировна — кандидат философских наук, доцент кафедры философии и культурологии Института истории, политических и социальных наук Петрозаводского государственного университета. Адрес: 185910, Россия, г. Петрозаводск, пр-т Аенина, А. 33. Тел.: +7 (814-2) 71-10-95. Эл. адрес: Larisa.Mihailova@gmail.com

Mikhailova Larisa Vladimirovna, Candidate of Philosophy Associate Professor, Department of Philosophy and Cultural Studies, Institute of History, Political and Social Sciences, Petrozavodsk State University. Postal address: 33, Lenina Ave., Petrozavodsk, Russian Federation 185910. Tel.: +7 (814-2) 71-10-95 E-mail: Larisa.Mihailova@gmail.com 